\title{
The Implications of Local Government Spending Efficiency on the Regional Economic Performance
}

\author{
Muhammad Heru Akhmadi \\ School of Financial Management \\ Polytechnic of State Finance of STAN \\ Tangerang Selatan, Indonesia \\ heru.cio@gmail.com
}

\author{
Imam Sumardjoko \\ Financial Analyst for Centers and Regions \\ Ministry of Finance \\ Jakarta, Indonesia \\ imamdjo@gmail.com
}

\begin{abstract}
Fiscal decentralization is an opportunity as well as a challenge for local government to improve the welfare of society through better economic manifestation. Regional economic performance is still a proud note during the implementation of fiscal decentralization. During 2011-2014, economic growth slowed and decreased by $6.49 \%, 6.26 \%, 5.73 \%$ and $5.06 \%$ respectively. The regional fiscal policy that was reflected in APBD contributed to the slowing economic performance. The increasing trend of regional spending each year does not automatically create better economic performance. APBD management that is pursued by reducing consumer spending, increasing PAD and enlarging capital expenditure allocation encourages the acceleration of regional development. On those matters, this research is aimed to see the influences of government expenditure specifically the efficiency of local government spending on the regional economic performance. The research uses quantitative method by using regression with estimation model of least square. The analysis involves variables of economic growth, regional capital expenditure, administrative expenditures, and the original income of growth areas; the control variables are gross fixed capital formation, population, and Constructive Cost Index. The research uses panel data sourced from APBD realization report in 20112015. The results prove that capital expenditure has an influence on regional economic improvement with the elasticity of 0.027 . Each $1 \%$ increase in capital expenditure will contribute $0.02 \%$ to an increase in the economic growth. The original revenue of the region significantly influenced the increase of regional economic growth during the research period with a p-value of 0.027 . Quality of spending has a high relation on the economic growth. A high quality spending of a region will be able to boost the economic growth and reduce poverty. Better provision of infrastructure will create inter-regional connectivity to promote local trade. Local governments should increase the accountability, value for money, probity, and transparency of APBD management as an effort to boost the region's economic growth.
\end{abstract} growth.

Keywords - local government; spending; infrastructure;

\section{INTRODUCTION}

The inequality problem of inter-regional development and fiscal disparity is the current fiscal decentralization issue. The toughest challenge in developing fiscal decentralization is not only to provide funds to local governments, but also to create an impact on improving the quality of public services and regional economic growth. Local governments have an important role in promoting socio-economic conditions of the community. The APBN allocated about $37 \%$ of total expenditure to be transferred to APBD in 2017. Government spending for local government transfer fund continued to increase every year and it exceeded the expenditures of ministries. Transfer to local government was set at Rp764.9 trillion or increased by $7.1 \%$ compared to APBN-P 2016. Comparing to the previous five years, the allocation of transfers to regions in 2017 doubled. The number of transfers to the regions continued to increase compared to the previous budget year. The APBN allocated about $37 \%$ of total expenditure to be transferred to APBD in 2017.

The increased allocation of transfer to local government has not maximally overcome poverty, equity of infrastructure, fiscal gap, and competitive regional economic development ${ }^{[1]}$. The Government pays close attention to the implementation of fiscal decentralization through transferring to regional instruments. As a result, the transfer amount to local government in the APBN increases every year. The implementation of the transfer transformation to the regions has not yet fully aroused the regional independence. Regional characteristics, geographic conditions, and resource availability are fundamental factors. Some regions have a high fiscal self-reliance ratio while many others still rely on central government transfers. The proportion of transfer funds to local government is still dominated by DAU and then special transfer funds.

The high dependence of local governments on balancing and adjusting funds indicates that PAD does not dominate the role as a locomotive of development in the regions. Transfers to the regional governments stimulate to accelerate the independence of local government ${ }^{[2]}$. The equitable development is subject to regional autonomy through the implementation of fiscal decentralization. The empirical evidence showed that the transfers from central government majorly affect the local spending on the provision of public services. ${ }^{[3]}$. The regional Budget (APBD) plays an important role in carrying out the functions of government to provide community services as well as a fiscal instrument in the region. The role is getting stronger in the era of fiscal decentralization. This condition creates strong consequences within the framework of accountability and transparency of the APBD. Implementating the government functions can work well if it is supported with adequate income. 
The APBD reflects the direction in achieving the vision and mission objectives that were set by the regions. The nature of regional missions is aimed to better economic progress. The realization and allocation of APBD reflect the performance of local financial management. The APBD also positively impacts on community ease and accessibility through economic development. The term of economic development is related to developing countries including Indonesia. In the era of regional autonomy, the strengthening of regional revenues and quality regional spending became important instruments in the economic development. The shift in local spending patterns as fiscal policy has influenced the economic and welfare trends of the people.

The regions are expected to be more optimum in exploring their potential income and using public funds based on their authority and aspirations ${ }^{[4]}$. This step is taken as an effort to move the economic sectors that will contribute to regional self-reliance. This is the argument for the government to implement fiscal decentralization policy. Law No. 33 of 2004 on Financial Balance of the Central and Regional Governments which provides flexibility in the management of regional finances.

Along with the regulation, local government can utilize the regional potency for regional development purpose. The philosophy of fiscal decentralization is to improve regional performance through government spending and revenue becoming more rational ${ }^{[5]}$. This effort is expected to provide public services improvement. The government becomes closer to the community through the delegation of authority and does direct control over APBD management.

The improvement of APBD is pursued by reducing consumer spending, increasing PAD and enlarging capital expenditure allocation to encourage the acceleration of regional development. The limitation of central government income is the issue why the efficiency of local budget allocation is needed. The regional efficiency ratio is measured by the ratio of total regional expenditures to regional expenditures ${ }^{[6]}$. The efficiency of local governments is reflected in the condition of small regional expenditures with high total regional revenues.

The low quality of government expenditure weakens the function of public services and ultimately affects to the achievement of regional progress ${ }^{[7]}$. The tendency of APBD planning pattern that has not involved community participation optimally resulted in low achievement of community welfare level. This condition is reflected in the allocation of local government expenditure in the APBD, especially the components of direct expenditure, so that it does not directly touch the economy. Based on Permendagri No. 13 Year 2006, direct expenditure is budgeted expenditure in connection to the implementation of programs and activities. The less balanced proportion of direct expenditure and indirect spending in the APBD structure triggers the slow pace of regional economic growth.

Studies on local spending become an interesting theme for researchers in various countries. This is shown by various studies and theories reviewing the effects of government spending on the economic growth. At this time, the government emphasizes the evaluation of the APBD spending effectiveness in line with the era of fiscal decentralization that has been running for more than fifteen years. The sociocultural and geographical characteristics become the dynamics in developing the area; so that, this study is expected to answer the government evaluation and to contribute in policy making related to regional finance. The increasing local spending every year does not necessarily lead to better economic performance.

\section{LITERATE REVIEW}

Economic growth illustrates an increase in economic activities affecting to the increase of goods and services productions and public welfare ${ }^{[8]}$. The economic growth reflects the development from one period to the next. According to Arsyad ${ }^{[9]}$, economic growth is associated with an increase in Gross Domestic Product/Gross National Income without considering the increase is greater or smaller than the rate of population growth.

Economic growth is one barometer of economic sustainability. The term growth has a different meaning with development (development). Growth is a criterion in development ${ }^{[10]}$. The dimension of economic development is wider than the economic growth. Measures of economic growth in a region can be determined by Gross Regional Domestic Income (GRDI). This figure describes the quantity of goods and services produced by all production units.

The neo classical economic growth model was built by Robert Solow and Swan. This model involves variables of population growth, capital accumulation, and the amount of output that interact. This theory states that output growth is caused by two main factors: capital and labor force. The assumption is a linear labor force with constant exponential growth. Capital variables include raw materials, machinery, equipment, buildings, and money. Capital components and labor force can be combined into various models. The aggregate production function in the Neoclassical Growth Model combines employment, capital, and the use of technology.

Neoclassical growth theory emphasizes the importance of the market in perfect condition. This model assumes investment as the same amount as saving. Thus, the tendency of people holding large amounts of cash results in slow economic growth. The neoclassical model suggests that a steady growth rate is sourced from large savings and reinvested corporate profits.

The level of the economy will be determined by aggregate spending. The condition in which there is full employment in the free market cannot always be formed. Therefore, the government actions in promoting economic growth are necessary. The role of government in influencing economic performance is not only through the monetary side but also the fiscal side of the APBN/APBD. Keyness argued that to prevent the economic slowdown, the government needs to 
spend on higher levels of national income. This step is necessary to keep pace the increasing trend of people's economy in the economy. The increase in capital spending reflects the provision of more adequate infrastructure. Facilities and infrastructure improvements encourage the economic growth. Creation of connectivity among regions will increase private investments. The development of public facilities and infrastructure through government capital expenditure will encourage economic growth in the region ${ }^{[11]}$. It is expected that adding infrastructure by local governments can drive the regional economic performance ${ }^{[12]}$. The first hypothesis is formulated as:

H1: Capital Expenditure has a positive effect on the improvement of regional economic growth.

Government spending in APBD is an important factor in stimulating regional economic performance, mostly since the introduction of regional autonomy and fiscal decentralization. Regional spending devoted to infrastructure development has an important role in creating the investment climate. In Bolivia, Faguet's $\mathrm{s}^{[13]}$ explained that fiscal decentralization increased public investments in education in accordance with local needs; while Sánchez ${ }^{[14]}$ proved that decentralization improved the quality of education, which affected the economic growth. The second hypothesis formulated in this study is as follow:

$\mathrm{H} 2$ : Regional expenditures affect regional economic growth.

The development of infrastructure and the provision of easy access can increase investment attractiveness. The provision of industrial infrastructure has a significant impact on the increase of local own revenues (PAD). Thus, local governments can levy larger taxes with the inclusion of private investment and public service users. Optimizing PAD revenues should be supported by local government by improving the quality of public services ${ }^{[15]}$. Better provision of public services and easy access to investment will certainly encourage regional economic growth. The third hypothesis is formulated as follow:

H3 : Local Revenue affects regional economic growth.

\section{RESEARCH METHOD}

This research used quantitative method by using explanatory approach with the intention of looking for new idea or relationship through hypothesis testing ${ }^{[16]}$. This study developed some previous researches combined with other variables that have not been studied related to the dynamics of the public economy. Hypothesis testing involved three independent variables namely capital expenditure, local revenue, and one dependent variable which is the allocation of regional economic growth.

The hypothesis testing applied regression analysis with Least Square approach; this technique was used to test the model of related equations. Panel data model used random effect method where the variation of direction value and direction of relationship between subjects are assumed random. The characteristic of this method is having the amount of cross section data which are bigger than the research variable. The random effect method was chosen based on Hausman's test after comparing to other methods such as fixed effect and Pooled Least Square. The study used secondary data sourced, APBD realization report from 2011 to 2015 and non-financial data from BPS. The observation area is all provinces in Indonesia with aggregate data of the province.

In accordance with the research question, the study model consists of several equations:

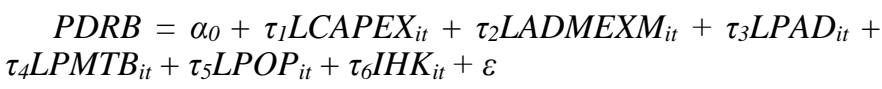

From the demand side, PDRB is a dependent variable in the form of regional gross domestic product using constant prices for each province; BMit is provincial government capital expenditure; BADMit is provincial government administrative expenditure; PADit is total revenue of aggregate region of province; PMTBit is the formation of gross fixed capital as a province; POPit is the aggregate population of the province; and IHKt is the price index of consumption in province.

\section{RESULT}

This study applied the regression equation since it contains the interrelated equations. The hypothesis in this study examined the effects of independent variables, which are balancing funds and adjustment funds to the dependent variable that is regional capital expenditure. The hypothesis testing used multiple linear regression analysis to obtain a comprehensive picture of the causality relationship between the two variables. The independent variable is the gross regional domestic product, while the independent variables of this equation are local capital expenditures, local administration expenditures, and indigenous opinions. The control variables include gross fixed capital formation, population, and consumer price index.

The parameter test result of regional economic performance estimation yielded the R-square value equal to $89,80 \%$. This result indicates that the model can explain the independent variable well. By using the least squares random effect regression, the result of regional economic performance estimation is as follows:

TABLE 1 ESTIMATED RESULTS OF REGIONAL ECONOMIC GROWTH

\begin{tabular}{lccc}
\hline \multicolumn{1}{c}{ Variable } & Coefficient & $\begin{array}{l}\text { Standard } \\
\text { Error }\end{array}$ & t-Statistics \\
\hline \hline $\begin{array}{l}\text { Capital } \\
\text { Expenditure }\end{array}$ & $0.027 * *$ & 0.0132 & 2.08 \\
$\begin{array}{l}\text { Administrative } \\
\text { Exp. }\end{array}$ & $0.102 * * *$ & 0.0340 & 3.00 \\
PAD & $0.068^{* *}$ & 0.0311 & 2.21
\end{tabular}


TABLE 1, CONT.

\begin{tabular}{llll}
\hline PMTB & $0.209 * * *$ & 0.0488 & 4.30 \\
Population & $0.662 * * *$ & 0.0733 & 9.03 \\
IHK & $0.050^{* * *}$ & 0.0008 & 6.63 \\
Const. & $7.887 * * *$ & 1.5533 & 5.08 \\
\hline \multicolumn{2}{c}{$* * * \mathrm{p}<0.01, * * \mathrm{p}<0.05, * \mathrm{p}<0.1$} & &
\end{tabular}

Based on the estimation of the regional economic growth, the overall independent variables of capital expenditure, administrative expenditure, PAD, PMTB, population and CPI influenced positively in increasing the economic growth at $1 \%$ level. Five percents of the test results support intergovernmental transfer theory on the implementation of fiscal decentralization in Indonesia. Of these variables, the population has the greatest influence on the growth of regional economy. This indicates that household consumption and society strongly influence the regional economic growth.

The first hyphothesis testing results Ho is rejected, which means there is a positive influence in the causal relationship. At $95 \%$ confidence level, it is concluded that the regional capital expenditure affects positively on the regional economic growth rate in the period of study. Thus $\mathrm{H} 1$ is supported in this study. The capital expenditure elasticity coefficient is 0.027 . It means that in ceteris paribus condition, every $1 \%$ increase of regional capital expenditure variable, will push regional economic growth rate equal to $2 \%$. Thus the realization of regional capital expenditure has a positive influence on the regional economy during the study period. It is proved that the increase of realization of local government capital expenditure improves the regional economic performance.

The test results indicate that a positive direction coefficient or an increase in capital expenditure will encourage regional economic growth. The results of this study are in line with the Theory of Economic Growth and previous researches by Kuncoro $^{[11]}$, Harianto ${ }^{[12]}$, as well as Abdullah and Halim ${ }^{[17]}$ stating that increased regional capital expenditure will boost economic performance. Regional expenditures which are increasing every year is triggered by the demands of public services that must be provided.

The philosophy of capital expenditure is a spending intended for a long term as a step to get the local government fixed assets. The provision of fixed assets by the local government suited to the priority of public services will impact in long term ${ }^{[18]}$. Capital expenditures are spent to develop and improve the infrastructure in the education, health and transport sectors so that more adequate public services are obtained. The availability of public services can create efficiency and effectiveness in various aspects. This is certainly an impact in increasing community productivity that will encourage regional economic growth.

Capital expenditures reflect the amount of infrastructure built up. The more development undertaken can drive regional economic performance. The expansion of better public services will increase investor appeal. Private investments will certainly impact on the expansion of employment and income per capita. This will have implications for regional economic growth. One of the important instruments in improving the economy is the support of capital expenditure in the framework of public investment.

The second hypothesis test proves that the expenditure of regional administration has a positive effect on the regional economic growth rate in the period of research with the elasticity of 0.102 . The test results reject Ho which means there is a positive influence in the causal relationship; tt a $95 \%$ confidence level. Thus $\mathrm{H} 2$ is supported in this study. In ceteris paribus condition, every $1 \%$ increase in variable of regional administration expenditure will push regional economic growth rate to $0.10 \%$.

The third hypothesis testing proves that the original revenue of the region positively affects on the regional economic growth rate in the period of research with the elasticity of 0.068 . The test results reject Ho which shows there is a positive influence in the causal relationship; at a 95\% confidence level. Thus H3 is supported in this study. In ceteris paribus conditions, every $1 \%$ increase in local indigenous opinion variable will encourage regional economic growth rate of $0.06 \%$.

The regional revenue sector plays a very important role in financing government activities and development spending. The government can encourage the increase of PAD through the collection of local taxes and levies with compensation of better infrastructure and public services. The provision of adequate services and facilities will encourage investor interest; so that will accelerate regional economic growth.

The regional autonomy benchmark can be seen from the proportion of local revenue to total regional income. The proportion of PAD reflects how local governments can finance their own activities through income components originating from the area. This study proves that PAD is able to boost the regional economic growth rate significantly. This review is in line with Florida's study which argued that local taxes and user charges can encourage local government financial performance ${ }^{[19]}$. This indicates that PAD is a component of regional expenditure financing that can be used to grow the regional economy.

Modeling the results of the above capital expenditure estimates can be formulated as follows:

LPDRBK $=7.887+0.01$ LCAPEX + 0.10 LADMEX + $0.03 \mathrm{LPAD}+0.04 \mathrm{LPMTB}+0.07 \mathrm{LPOP}+0.005 \mathrm{IHK}$

\section{CONCLUSION}

The productivity improvement in APBD is pursued by reducing consumer spending, increasing PAD and enlarging capital expenditure allocation to encourage the acceleration of regional development. The limitations of income are central to the allocation of local budgets; so that efficiency is needed. The efficiency of local governments is reflected in the condition of small regional expenditures with high total regional revenues. 
Regional capital expenditure has a positive influence on regional economic growth in Indonesia of $0.027 * *$. These results indicate that every $1 \%$ increase in regional capital expenditure will increase regional economic growth by $0.02 \%$. Capital expenditure is one form of government investment. Capital expenditure has a multiplier effect that can directly stimulate regional economic growth.

The administration spending has a positive effect on regional economic growth with a value of $0.102 * * *$. The increase in administrative expenditure in APBD will encourage economic growth in the area. The APBD expenditure administration is much aimed at the operational needs of welfare governance so that it can trigger purchasing power and encourage regional economic growth.

Local revenue is positively affected by regional economic growth with a value of $0.068 * * *$. Increased local revenue will encourage economic growth in the region. Regional revenue plays a very important role in financing government activities and development expenditures.

\section{REFERENCES}

[1] Agus D.W Martowardojo, 2011, Peningkatan kualitas hubungan Keuangan Pusat dan Daerah dalam mendorong pertumbuhan ekonomi.

[2] Naganathan, M. dan K.J. Sivagnanam, 1999, Federal Transfers and Tax Efforts of States in India, Indian Economic Journal, 47(4)

[3] Legrenzi. Gabriella dan Costas Milas. 2001. Non-Linier and Asymetrics Adjustment In The Local RevenueExpenditure Models: Some Evidence From The Italian Municipalities. Working Paper. University of Milan

[4] Mardiasmo, 2002, Otonomi dan Manajemen Keuangan Daerah. Penerbit ANDI, Yogyakarta

[5] Ahmad Hafidh, Aula, 2013, Analisis Rasio Keuangan Daerah dalam Mempengaruhi Belanja Modal Publik Bagi Pertumbuhan Ekonomi. Jurnal Penelitian Humaniora. Vol. 18 No. 2, Oktober 2013

[6] Mediaty, 2010, Pengaruh Partisipasi Anggaran Dan Gaya Kepemimpinan Terhadap Kinerja Aparatur Pemerintah
Daerah Provinsi Sulaweai Selatan, Majalah Ekonomi Desember 2010, Vol. 20 No. 3

[7] Sukirno, Sadono. 2000. Ekonomi Pembangunan Proses, Masalah dan Dasar Kebijakan Pembangunan. UI-Press. Jakarta.

[8] Arsyad, 1999, Pengantar Perencanaan dan Pembangunan Ekonomi Daerah, Edisi Pertama, BPFE, Yogyakarta.

[9] Clinard, Marshall B. dan Robert F. Meier, 1989, Sociology of Deviant Behavior.Chigago: Holt,Reinhart and Winston, Inc

[10] Kuncoro, Mudrajat, 2004, Otonomi dan Pembangunan Daerah, Erlangga, Jakarta.

[11] Adi, Priyo Hari, dan Harianto, David, 2007, Hubungan antara Dana Alokasi Umum, Belanja Modal, Pendapatan Asli Daerah dan Pendapatan Per Kapita. Makasar : Simposium Nasional Akuntansi X.

[12]Faguet, J.P, 2004, Does decentralization increase responsiveness to local needs? Evidence from Bolivia, Journal of Public Economics, 88: 867-894.

[13] Sánchez, F. and A. Diaz, 2007, Los efectos sociales del conflicto armado interno, in Fabio Sánchez (ed.) Las Cuentas de la Violencia, Bogotá: Editorial Norma.

[14] Global Reporting Initiative, 2014, Pedoman Laporan Keberlanjutan. www.globalreporting.org

[15] Hasan, M. Iqbal, 2002, Pokok-pokok Materi Metodologi Penelitian dan Aplikasinya, Ghalia Indonesia, Bogor,

[16] Halim, Abdul, Damayanti, Theresia, 2007, Pengelolaa n Keuangan Daerah, Seri Bunga Rampai Manajemen Keuangan Daerah, UPP STIM YKPN, Yogyakarta.

[17] Ardhani, Pungky, 2011, Pengaruh Pertumbuhan Ekonomi, Pendapatan Asli Daerah, Dana Alokasi Umumdn Dana lokasi Khusus terhadap Pengalokasian Anggaran Belanja Modal. Skripsi Universitas Diponegoro

[18] Asha Florida, 2007, Pendapatan Asli Daerah (PAD) terhadap Kinerja Keuangan Pemerintah Kabupaten dan Kota di Propinsi Sumatera Utara. Universitas Sumatera Utara. Medan

[19] Rondinelli, Dennis A dan G. Shabbir Cheema, 2000. Implementing Decentralization Policies; An Introduction, Beverly Hills/London/New Delhi:Sage Publication 